\title{
The Dacini fruit fly fauna of Sulawesi fits Lydekker's line but also supports Wallacea as a biogeographic region (Diptera, Tephritidae)
}

\author{
Camiel Doorenweerd', Arni Ekayanti², Daniel Rubinoff' \\ I University of Hawaii, College of Tropical Agriculture and Human Resources, Department of Plant and En- \\ vironmental Protection Sciences, Entomology section, 3050 Maile Way, Honolulu, Hawaii, 96822-2231, USA \\ 2 Niogret Ecology Consulting LLC, Wotu, Luwu Timor, Sulawesi Selatan 92971, Indonesia \\ Corresponding author: Camiel Doorenweerd (camiel.doorenweerd@hawaii.edu)
}

Academic editor: Teresa Vera | Received 10 June 2020 | Accepted 24 August 2020 | Published 5 October 2020

http://zoobank.org/441DE60D-1A44-4240-B64A-B0A88F101D5E

Citation: Doorenweerd C, Ekayanti A, Rubinoff D (2020) The Dacini fruit fly fauna of Sulawesi fits Lydekker's line but also supports Wallacea as a biogeographic region (Diptera, Tephritidae). ZooKeys 973: 103-122. https://doi. org/10.3897/zookeys.973.55327

\begin{abstract}
Although there is scientific consensus on most of the major biogeographic regions in the world, the demarcation of the area connecting Southeast Asia with Australia and Oceania remains debated. Two candidate boundaries potentially explain faunistic diversity patterns in the regions: Lydekker's and Wallace's lines. The islands in between both 'lines' are jointly termed Wallacea, with Sulawesi as the largest landmass. We surveyed Dacini fruit flies (Tephritidae: Dacinae) in Sulawesi between 2016 and 2019 using traps baited with male lures, resulting in 4,517 collected flies. We identified all specimens to species level, which adds 15 new species records to the island, bringing the total number of Dacini species in Sulawesi to 83. The biogeographic affinity of species in the updated checklist reveals a strong connection with former 'Sunda' ( $41 \%$ of species); validating Lydekker's line, but also a high level of endemism ( $47 \%$ of species), confirming the uniqueness of Wallacea as a biogeographic region. We further describe a new species, Bactrocera (Bactrocera) niogreta Doorenweerd, sp. nov. and discuss the taxonomy of several interesting species.
\end{abstract}

\section{Keywords}

Bactrocera, biogeography, Dacus, pest, taxonomy, Zeugodacus, zoogeographic 


\section{Introduction}

Biogeographic boundaries were initially established to indicate stark and sudden differences between faunas of neighboring areas, as noted by early explorers like Alfred Russel Wallace, and proved fundamental to the understanding of tectonic plate movement (Wallace 1876; Lydekker 1896; Mayr 1944; Simpson 1977; Whitmore 1982). Today, they incorporate phylogenetic considerations and define biogeographical regions that can be of broad practical use including for regional identification keys, for understanding dispersal patterns, and designation of biogeographic hotspots for critical conservation considerations (Kreft and Jetz 2010; van Welzen et al. 2011; Holt et al. 2013). The area that connects Southeast Asia with Australia - also termed the Malay Archipelago or Malesia - probably contains the largest number of named biogeographic boundaries anywhere on the planet (Simpson 1977). The two designations that have held up best following extensive studies of both fauna and flora are known as Wallace's line and Lydekker's line, with the area in between often referred to as Wallacea (Fig. 1).

Wallace's line runs south of the Philippines, east of Borneo and continues south between Bali and Lombok (van Welzen et al. 2011). The boundary was hypothesized in works by Wallace (1860), and not long after the term "Wallace's line" was coined by Huxley (1868). Islands and landmasses west of Wallace's line are jointly termed the Sunda Shelf and were intermittently connected by land during the Pleistocene ice ages, up to as recently as 21,000 years ago when the sea level was as much as $120 \mathrm{~m}$ below current levels (for a review see van Welzen et al. 2011). Lydekker's line, on the other hand, suggests an alternative separation that would potentially explain the broader faunistic diversity patterns in the regions better. It was proposed by Lydekker (1896), but its significance became more recognized in later studies (Simpson 1977). This boundary runs west of Papua and north of Australia. Papua and Australia are located on the Sahul Shelf and were connected by land during roughly the same periods where Sundaland existed. There has been much debate on which line more accurately indicates the changes in biodiversity composition in the Indomalayan region (Simpson 1977; van Welzen et al. 2011). In some studies, the area between Wallace's and Lydekker's lines has been termed Wallacea and interpreted as a separate biogeographic region altogether, as it generally has high levels of endemism. Sulawesi is the largest island in Wallacea, where it is joined with the Moluccas and the lesser Sunda Islands. The area has known substantial geological turmoil: Sulawesi was separated into three parts until the late Miocene $(-10 \mathrm{Ma})$. It was cut into the West Sulawesi ophiolite and North Sulawesi ophiolite that have a closer geographic affinity to Eurasia, and the East Sulawesi ophiolite, which was geographically closer to Australia (Hall 1998; Spakman and Hall 2010). The exact timing of the joining of these fragments is still uncertain, partly because it is unclear which areas were submerged in the past $10 \mathrm{Ma}$ (Hall 2009). In any case, the geographic history of the islands has undoubtedly played a large role in the evolution of the fauna of the Sulawesi.

Dacini fruit flies (Tephritidae: Dacinae) are a tribe of 938 described exclusively Old World species (e.g., Doorenweerd et al. 2018). They are mostly known for their 


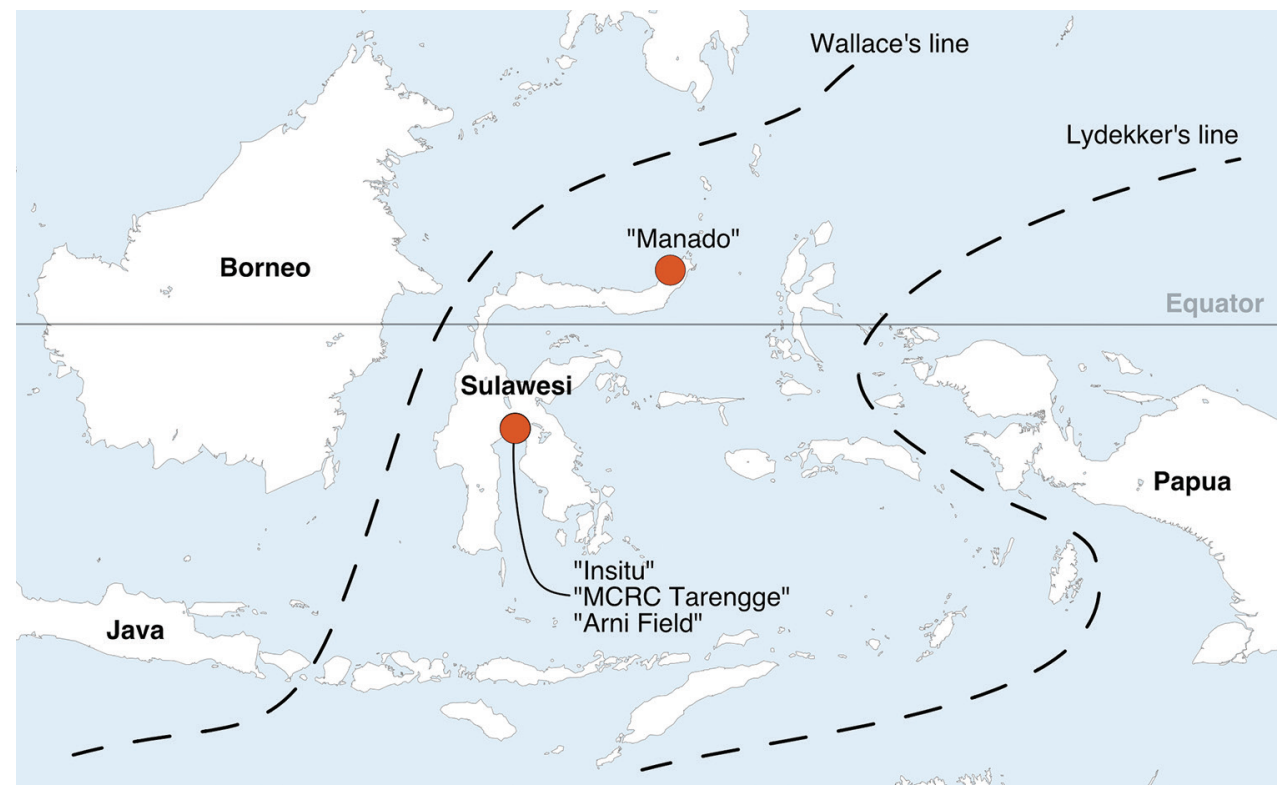

Figure I. Map of Sulawesi and neighboring areas showing the four sampling localities with orange spots; the three localities in South Sulawesi were in close proximity to each other. Two typical biogeographical boundaries are indicated with dotted lines: Wallace's line and Lydekker's line. Land masses west of Wallace's line were connected during ice ages as Sunda, east of Lydekker's line land masses were connected as Sahul. Islands in between the two biogeographical boundaries were never connected by land and are jointly known as Wallacea.

potential to damage fruit crop production, as the majority of species are frugivorous and the larvae will feed on many fleshy fruits also used for human consumption (Vargas et al. 2015; Ekesi et al. 2016). The taxonomic and phylogenetic insights in the group have only recently begun to stabilize (Schutze et al. 2015, 2017; Dupuis et al. 2018; San Jose et al. 2018a), and there are likely many species yet undescribed. The first recorded Dacini fruit flies from Sulawesi were four species collected by Wallace in the mid $19^{\text {th }}$ century (Hardy 1982). After those initial collections, the Dacini fauna of the island went unstudied for over a century until Hardy recorded 34 species during a sabbatical leave in 1975 (Hardy 1982). Many of those species were new to science and are endemic to Sulawesi. More recent studies have added further records (Drew and Romig 2013; Drew and Hancock 1994), and this current study adds another 15, which brings the total of Dacini fruit fly species known from Sulawesi to 83 . We here provide a checklist of all species, describe Bactrocera (Bactrocera) niogreta sp. nov. as new to science and discuss new species forms, and assess the faunistic affinity of Sulawesi Dacini with neighboring biogeographic areas. In the last comprehensive overview, Hardy wrote: "The Dacus [ed: now Dacini] of Sulawesi fit more closely with the fauna of the Australian Region than with that of the Oriental". The Australian region in this sense included the Moluccas and Papua, thus agreeing with Wallace's line. We re-evaluate this statement based on the updated species list. 


\section{Materials and methods}

\section{Sampling}

We collected Dacini flies using handmade bottle traps. A $3 \mathrm{~cm}$-diameter hole was cut 15 $\mathrm{cm}$ from the base of a $500 \mathrm{ml}$ plastic water bottle. Male attractant lures: methyl eugenol $10 \mathrm{~g}$ cones (Scentry Biologicals Inc., Billings MT, USA), cue lure $2 \mathrm{~g}$ cones (Scentry Biologicals Inc., Billings MT, USA), and zingerone (Sigma-Aldrich, St. Louis MO, USA) were individually suspended by a string inside the bottle, $5 \mathrm{~cm}$ from the top. A $100 \mathrm{ml}$ water solution of Fisherbrand Sparkleen detergent (Fisher Scientific, Pittsburgh, PA, USA) poured at the bottom of each bottle trap was used as a killing agent. The traps were then hung from a cacao tree (Theobroma cacao L.) branch at $1.5 \mathrm{~m}$ high. Traps were checked every 2-5 days, and trapped flies were transferred to 95\% ethanol. Trapping was mainly conducted in Wotu, Kabupaten Luwu Timur, South Sulawesi at sites named "Insitu" [WGS84 N 2.5587 E 120.7935], "MCRC Tarengge" [WGS84 N 2.5547 E 120.8047] and "Arni field" [WGS84 N 2.5587 E 120.7935] (Fig. 1).

Planting at Insitu was composed primarily of cacao clones PBC123 and BR25 that were planted $3.5 \mathrm{~m}$ apart within a row, with $3.5 \mathrm{~m}$ spacing between rows, irregularly shaded by a diversity of fruit trees. This site was the most diversified among the trapping sites, including more than 100 banana (Musa sp.), four large durian tree (Durio sp.), eight rambutan (Nephelium lappaceum L.), six coconut trees (Cocos nucifera L.), as well as some ginger (Alpinia sp.), Luffa (Luffa acutangula L.), papaya (Carica papaya L.), chili peppers (Capsicum sp.) and corns. The cacao trees were not regularly pruned but were treated with an unknown pesticide, and were not artificially irrigated. This farm was surrounded by neighboring cacao farms with a similar diversified composition. In addition, some jackfruit (Artocarpus heterophyllus Lam.), mango (Mangifera indica L.), guava (Psidium guavaja L.), rose apple (Syzygium sp.), as well as breadfruit (Artocarpus altilis (Parkinson) Fosberg) were present around the neighboring farms. The site at MCRC Tarengge represents a 1 ha of cacao trees of clone M01 with a $1.5 \times 3$ m density, without any other fruit trees within the block. However, several langsat trees (Lansium parasiticum (Osbeck) Sahni \& Bennet), banana and a couple of durian trees were present in the neighborhood farms $100 \mathrm{~m}$ away from the trapping sites, as well as 20 papaya, 10 rambutan trees (Nephelium lappaceum L.) within $200 \mathrm{~m}$, and several mango trees, jackfruit, guava, and rose apple trees within $400 \mathrm{~m}$ radius from the trapping site. No pesticide was applied during our field collection, but both surrounding blocks were regularly treated with pesticides. The site 'Arni field' was also mainly composed of cacao trees at lower density $(3 \times 3 \mathrm{~m})$. Various fruit trees disseminated around the farm, including some banana, rambutans, jackfruit, mangos, guava, and Ambarella (Spondias dulcis L.), with rows of corn (Zea mays L.) and several durian trees within $50 \mathrm{~m}$, as well as jambu putik (Syzygium sp.), rose apple, and breadfruit within $300 \mathrm{~m}$.

In total, the trapping effort at Arni field was approximately four months, five months at MCRC Tarengge, and six and half months at Insitu, spread over different periods during 2016-2019 (Suppl. material 1: Table S1). The site "Manado" [WGS84 $1.3973 \mathrm{~N}, 124.6488 \mathrm{E}]$, near the city of Manado in North Sulawesi, had three 
trapping days. At all sites combined, we collected 4,517 Dacini flies and identified all specimens to species level, initially based on external morphology. In cases where the morphology was inconclusive, we used DNA sequences of Cytochrome C Oxidase I and/or Elongation Factor 1-alpha for a total evidence identification approach. In 2016, some additional collecting was done with torula yeast dissolved in water, which attracts females. A full overview of all traps and localities can be found in Suppl. material 1: Table S1. All voucher material is stored at the University of Hawaii Insect Museum (UHIM). Photographs of adult specimens were taken using a Zeiss Discovery.V8 stereomicroscope with an attached Sony alpha-6300 camera. Photographs from multiple focal plains were combined into a single stacked image using Affinity Photo 1.7.3 and optimized for publication. Plates with multiple images were assembled in Affinity Designer 1.7.3. Wings of selected specimens were removed and mounted in euparal on glass-slides and photographed in a similar manner as the adults.

\section{DNA extraction, PCR, sequencing, and analyses}

Methods for DNA extraction, PCR primers and conditions, and Sanger sequencing follow those of San Jose et al. (2018a). For the present study, we sequenced a Cytochrome C Oxidase I (COI) 809 base pair 3P' fragment and an Elongation Factor 1-alpha (EF1alpha) 762 bp gene fragment for Bactrocera niogreta. We compared the sequences to our (partially unpublished) sequence database and here release sequences of the most closely related species to establish the diagnostic discrimination of COI and EF1-a sequences. We also sequenced COI and EF1-a for several specimens of Bactrocera melastomatos Drew \& Hancock, 1994 and Dacus longicornis (Wiedemann, 1830), to confirm if the different morphological forms were mirrored in mitochondrial and/or nuclear genetic variation. Finally, we sequenced EF1-alpha for the two specimens of $B$. carambolae Drew \& Hancock, 1994, which is diagnostic at five positions, to confirm its identity (see also Leblanc et al. 2019). All specimen collecting details and DNA sequences are available through BOLD dataset DOI: http://dx.doi.org/10.5883/DSDACSU, and GenBank accessions: MT456325-MT456363 [COI] and MT456286MT456324 [EF1-alpha]). We performed maximum likelihood analyses for each subset of sequences using IQTree 1.6.10 (Nguyen et al. 2015). We allowed IQTree to determine the substitution model via its integrated modeltest and ran maximum likelihood analyses with 5,000 ultrafast bootstraps and 5,000 Sh-aLRT bootstraps. We consider branches with support values $>95 \%$ for ultrafast bootstraps and $>80 \%$ for Sh-aLRT bootstraps as well supported. Resulting trees were optimized for publication using FigTree 1.4.3 and Affinity Designer 1.7.3.

\section{Results}

We list 83 species of Dacini for Sulawesi (Table 1): 51 species of Bactrocera, 7 Dacus, and 25 Zeugodacus. We collected 29 species during our surveys, of which 15 are new island records. The biogeographic affinity of most species is with the Sunda region; 34 
Table I. Checklist of Dacini in Sulawesi.

\begin{tabular}{|c|c|c|c|c|c|c|c|}
\hline Species & Sulawesi record & Male lure & Insitu & $\begin{array}{c}\text { MCRC } \\
\text { Tarengge }\end{array}$ & $\begin{array}{l}\text { Arni } \\
\text { Field }\end{array}$ & Manado & $\begin{array}{c}\text { Biogeographic } \\
\text { affinity }\end{array}$ \\
\hline B. abbreviata (Hardy, 1974) & This study & $\mathrm{ZN}$ & $\mathrm{x}$ & & $\mathrm{x}$ & & Sunda \\
\hline B. affinibancroftii Drew \& Romig, 2013 & Drew and Romig 2013 & ME & & & & & Sulawesi endemic \\
\hline B. affinidorsalis (Hardy, 1982) & Hardy 1982 & CL & & & & & Sunda \\
\hline B. albistrigata de Meijere, 1911 & Drew and Romig 2013 & $\mathrm{CL}$ & $\mathrm{x}$ & $\mathrm{x}$ & $\mathrm{x}$ & $\mathrm{x}$ & Sunda \\
\hline B. beckerae (Hardy, 1982) & Hardy 1982 & $\mathrm{CL}$ & & & & & Sulawesi endemic \\
\hline B. bifasciata (Hardy, 1982) & Hardy 1982 & $\mathrm{CL}$ & & & & & Wallacea \\
\hline B. bitungiae Drew \& Romig, 2013 & Drew and Romig 2013 & $\mathrm{CL}$ & & & & & Sulawesi endemic \\
\hline B. carambolae Drew \& Hancock, 1994 & This study & ME & $\mathrm{x}$ & & & & Sunda \\
\hline B. careofascia Drew \& Romig, 2013 & Drew and Romig 2013 & $\mathrm{CL}$ & & & & & Sulawesi endemic \\
\hline B. commensurata Drew \& Romig, 2013 & This study & ME & $\mathrm{x}$ & $\mathrm{x}$ & $\mathrm{x}$ & & Sunda \\
\hline B. curvosterna Drew \& Romig, 2013 & Drew and Romig 2013 & $\mathrm{CL}$ & & & & & Sulawesi endemic \\
\hline B. dispar (Hardy, 1982) & Hardy 1982 & - & & & & & Sulawesi endemic \\
\hline B. dorsalis (Hendel, 1912) & Drew and Romig 2013 & ME & $\mathrm{x}$ & $\mathrm{x}$ & $\mathrm{x}$ & $\mathrm{x}$ & Sunda \\
\hline B. elongata Drew \& Romig, 2013 & Drew and Romig 2013 & $\mathrm{CL}$ & & & & & Sulawesi endemic \\
\hline B. flavipennis (Hardy, 1982) & Hardy 1982 & CL & & & & & Sulawesi endemic \\
\hline B. flavosterna Drew \& Romig, 2013 & Drew and Romig 2013 & $\mathrm{CL}$ & & & & & Sulawesi endemic \\
\hline B. floresiae Drew \& Hancock, 1994 & Drew and Romig 2013 & ME & & & & & Sunda \\
\hline B. fuscitibia Drew \& Hancock, 1994 & Drew and Romig 2013 & $\mathrm{CL} / \mathrm{ZN}^{*}$ & & & & & Sunda \\
\hline B. fuscolobata Drew \& Romig, 2013 & Drew and Romig 2013 & $\mathrm{CL}$ & $\mathrm{x}$ & & & & Sulawesi endemic \\
\hline B. fuscoptera Drew \& Romig, 2013 & Drew and Romig 2013 & ME & & & & & Sulawesi endemic \\
\hline B. hantanae Tsuruta \& White, 2001 & This study & $\mathrm{CL}$ & $\mathrm{x}$ & & & & Sunda \\
\hline B. infulata Drew \& Hancock, 1994 & Drew and Hancock 1994 & ME & & & & & Sulawesi endemic \\
\hline B. involuta (Hardy, 1982) & Hardy 1982 & CL & & & & & Sulawesi endemic \\
\hline B. latifrons (Hendel, 1915) & Drew and Romig 2013 & - & & & & & Sunda \\
\hline B. limbifera (Bezzi, 1919) & Drew and Romig 2013 & $\mathrm{CL}$ & $\mathrm{x}$ & $\mathrm{x}$ & & $\mathrm{x}$ & Sunda \\
\hline B. linduensis Drew \& Romig, 2013 & Drew and Romig 2013 & CL & $\mathrm{x}$ & & & & Wallacea \\
\hline B. megaspilus (Hardy, 1982) & Hardy 1982 & $\mathrm{CL}$ & & & $\mathrm{x}$ & & Sulawesi endemic \\
\hline B. melastomatos Drew \& Hancock, 1994 & This study & $\mathrm{CL}$ & $\mathrm{x}$ & $\mathrm{x}$ & $\mathrm{x}$ & & Sunda \\
\hline B. moluccensis (Perkins, 1939) & Drew and Romig 2013 & $\mathrm{CL} / \mathrm{ZN}$ & & & & & Sunda \\
\hline B. nanoarcuata Drew \& Romig, 2013 & Drew and Romig 2013 & $\mathrm{CL}$ & & & & & Sulawesi endemic \\
\hline B. nationigrotibialis Drew \& Romig, 2013 & Drew and Romig 2013 & ME & & & & & Sulawesi endemic \\
\hline B. neoritsemai Drew \& Romig, 2013 & Drew and Romig 2013 & $\mathrm{CL}$ & & & & & Sulawesi endemic \\
\hline B. niogreta Doorenweerd sp. nov. & This study & $\mathrm{ZN}$ & $\mathrm{x}$ & & & & Sulawesi endemic \\
\hline B. ochroma Drew \& Romig, 2013 & Drew and Romig 2013 & ME & & & & & Sunda \\
\hline B. pendleburyi (Perkins, 1938) & This study & $\mathrm{ZN}$ & & $\mathrm{x}$ & $\mathrm{x}$ & & Sunda \\
\hline B. penebeckerae Drew \& Romig, 2013 & Drew and Romig 2013 & - & & & & & Wallacea \\
\hline B. penecostalis Drew \& Romig, 2013 & Drew and Romig 2013 & CL & & & & & Sulawesi endemic \\
\hline B. perkinsi (Drew \& Hancock, 1981) & This study & $\mathrm{CL}$ & $\mathrm{x}$ & & & & Sahul \\
\hline B. pernigra Ito, 1983 & This study & $\mathrm{CL}$ & & & & & Sunda \\
\hline B. propinqua (Hardy \& Adachi, 1954) & This study & CL & $\mathrm{x}$ & & & & Sunda \\
\hline B. pseudobeckerae Drew \& Romig, 2013 & Drew and Romig 2013 & $\mathrm{CL}$ & & & & & Sulawesi endemic \\
\hline B. ritsemai (Weyenbergh, 1869) & Drew and Romig 2013 & $\mathrm{CL}$ & & & & & Sunda \\
\hline B. splendida (Perkins, 1938) & This study & $\mathrm{ZN}^{*}$ & $\mathrm{x}$ & & & & Sunda \\
\hline B. sulawesiae Drew \& Hancock, 1994 & Drew and Hancock 1994 & ME & & & & & Sulawesi endemic \\
\hline B. suliae Drew \& Romig, 2013 & Drew and Romig 2013 & ME & & & & & Wallacea \\
\hline B. syzygii White \& Tsuruta, 2001 & This study & $\mathrm{ZN}$ & $\mathrm{x}$ & $\mathrm{x}$ & $\mathrm{x}$ & & Sunda \\
\hline B. terminifer (Walker, 1860) & Drew 1989 & - & & & & & Sulawesi endemic \\
\hline B. trifasciata (Hardy, 1982) & Hardy 1982 & $\mathrm{CL}$ & & & & & Sulawesi endemic \\
\hline B. umbrosa (Fabricius, 1805) & Drew and Romig 2013 & ME & $\mathrm{x}$ & $\mathrm{x}$ & $\mathrm{x}$ & $\mathrm{x}$ & Sunda; Sahul \\
\hline B. usitata Drew \& Hancock, 1994 & This study & $\mathrm{CL}$ & $\mathrm{x}$ & & & & Sunda \\
\hline B. wuzhishana Li \& Wang, 2006 & Drew and Romig 2013 & ME & & & & & Sunda \\
\hline D. donggaliae Drew \& Romig, 2013 & Drew and Romig 2013 & $\mathrm{CL}$ & & & & & Sulawesi endemic \\
\hline D. longicornis (Wiedemann, 1830) & Walker 1860; Drew 1989 & $\mathrm{CL}$ & $\mathrm{x}$ & & & & Sunda \\
\hline D. melanopectus Drew \& Romig, 2013 & Drew and Romig 2013 & ME & & & & & Sulawesi endemic \\
\hline D. nanggalae Drew \& Hancock, 1998 & Drew and Hancock 1998 & CL & & & & & Sulawesi endemic \\
\hline D. ortholomatus Hardy, 1982 & Hardy 1982 & - & & & & & Sulawesi endemic \\
\hline D. pedunculatus (Bezzi, 1919) & This study & $\mathrm{ZN}^{*}$ & $\mathrm{x}$ & $\mathrm{x}$ & & & Sunda \\
\hline
\end{tabular}




\begin{tabular}{|c|c|c|c|c|c|c|}
\hline Species & Sulawesi record & Male lure & Insitu & $\begin{array}{c}\text { MCRC } \\
\text { Tarengge }\end{array}$ & $\begin{array}{l}\text { Arni Manado } \\
\text { Field }\end{array}$ & $\begin{array}{l}\text { Biogeographic } \\
\text { affinity }\end{array}$ \\
\hline D. pullus (Hardy, 1982) & Hardy 1982 & $\mathrm{ZN}^{*}$ & $\mathrm{x}$ & & & Sulawesi endemic \\
\hline Z. abnormis (Hardy, 1982) & Hardy 1982 & $\mathrm{CL}$ & & & & Sunda \\
\hline Z. angustifinis (Hardy, 1982) & Hardy 1982 & CL & $\mathrm{x}$ & & & Sulawesi endemic \\
\hline Z. apicalis (de Meijere, 1911) & Hardy 1982 & $\mathrm{CL}$ & $\mathrm{x}$ & & & Sunda \\
\hline Z. bogorensis (Hardy, 1983) & Hardy 1982 & $\mathrm{CL}$ & & & & Sunda \\
\hline Z. buruensis (White, 1999) & Hardy 1982 & CL & & & & Wallacea \\
\hline Z. connexus (Hardy, 1982) & Hardy 1982 & - & & & & Sulawesi endemic \\
\hline Z. cucurbitae (Coquillett, 1899) & Drew and Romig 2013 & CL & $\mathrm{x}$ & $\mathrm{x}$ & & Sunda \\
\hline Z. dubiosus (Hardy, 1982) & Hardy 1982 & $\mathrm{CL}$ & & & & Sulawesi endemic \\
\hline Z. emittens (Walker, 1860) & Walker 1860; Drew 1989 & $\mathrm{CL}$ & & & & Wallacea \\
\hline Z. eurylomatus (Hardy, 1982) & Hardy 1982 & - & & & & Sulawesi endemic \\
\hline Z. exornatus (Hering, 1941) & Drew and Romig 2013 & CL & $\mathrm{x}$ & & & Sunda \\
\hline Z. flavipilosus (Hardy, 1982) & Drew and Romig 2013 & $\mathrm{CL}$ & & & & Sulawesi endemic \\
\hline Z. fulvipes (Perkins, 1938) & Hancock and Drew 2017 & CL & & & & Sunda \\
\hline Z. hancocki (Drew \& Romig, 2013) & Drew and Romig 2013 & $\mathrm{CL}$ & & & & Sulawesi endemic \\
\hline Z. heinrichi (Hering, 1941) & Hering 1941 & $\mathrm{CL} / \mathrm{ZN}$ & & & & Sunda \\
\hline Z. melanopsis (Hardy, 1982) & Hardy 1982 & $\mathrm{CL}$ & & & & Sulawesi endemic \\
\hline Z. neoflavipilosus (Drew \& Romig, 2013) & Drew and Romig 2013 & CL & & & & Sulawesi endemic \\
\hline Z. neolipsanus (Drew \& Romig, 2013) & Drew and Romig 2013 & $\mathrm{CL}$ & & & & Wallacea \\
\hline Z. persignatus (Hering, 1941) & Drew and Romig 2013 & $\mathrm{CL}$ & $\mathrm{x}$ & & & Wallacea \\
\hline Z. proprescutellatus (Zhang Che \& Gao, 2011) & This study & $\mathrm{CL}$ & $\mathrm{x}$ & & & Sunda \\
\hline Z. synnephes (Hendel, 1913) & Drew and Romig 2013 & $\mathrm{CL}$ & & & & Sunda \\
\hline Z. tebeduiae (Drew \& Romig, 2013) & Drew and Romig 2013 & $\mathrm{CL}$ & & & & Sunda \\
\hline Z. transversus (Hardy, 1982) & Hardy 1982 & $\mathrm{CL}$ & $\mathrm{x}$ & & & Sulawesi endemic \\
\hline Z. ujungpandangiae (Drew \& Romig, 2013) & Drew and Romig 2013 & $\mathrm{CL}$ & & & & Sulawesi endemic \\
\hline$Z$. vargus (Hardy, 1982) & Hardy 1982 & $\mathrm{CL}$ & & & & Sulawesi endemic \\
\hline
\end{tabular}

*: new lure record. Male lure abbreviations: $\mathrm{ME}$ = methyl eugenol, $\mathrm{CL}=$ cue lure, $\mathrm{ZN}$ = zingerone.

of the species in the checklist can also currently be found in areas formerly connected under Sunda. This is in stark contrast with affinities related to Sahul; only one species is currently also found there, and an additional single species is found across Sunda, Wallacea and Sahul (B. umbrosa (Fabricius, 1805); see also Krosch et al. 2018). All 47 other species are endemic to Wallacea, and 39 of those are known from Sulawesi only, indicating the high levels of endemicity of the region, even for these volant insects.

We report four new male lure records of species attracted to zingerone: Bactrocera splendida (Perkins, 1938), B. fuscitibia Drew \& Hancock, 1994 (attracted to both cue lure and zingerone), Dacus pedunculatus (Bezzi, 1919), and D. pullus (Hardy, 1982). Although the three localities "Insitu", "MCRC Tarengge" and "Arni Field" are geographically within two kilometers of each other, Insitu had a distinctly higher diversity with 28 species, whereas we only collected ten species at MCRC Tarengge, and nine at the Arni Field, with similar collecting efforts. We collected only four species at the "Manado" site, but this is likely due to less trapping days, and possibly because this was a less forested site just $50 \mathrm{~m}$ from the coastline. The major, widely distributed, pest species B. albistrigata (de Meijere, 1911) and B. dorsalis (Hendel, 1912) were present at all sites and made up $70.6 \%$ of all specimens collected (Suppl. material 1: Table S1).

Below, we describe two new species, provide more information on the first records of B. carambolae for Sulawesi, and discuss the presence of B. melastomatos. We also describe the second specimen ever collected of Dacus pullus, and provide morphological and molecular evidence for two species forms of Dacus longicornis. 


\section{Bactrocera (Bactrocera) niogreta Doorenweerd, sp. nov.} http://zoobank.org/AEC5FE4F-A4F4-4C48-AEB6-27A1A74B6F58 Figures 2-7

Holotype. Male. Labelled: "Indonesia: Sulawesi: South Sulawesi: Insitu. WGS84 -2.5464 120.7921 16-23.i.2019 Zingerone trap. Leg. Jerome Niogret. DNA sample ms09121". Deposited at the University of Hawaii Insect Museum (UHIM).

Differential diagnosis. Bactrocera (Bactrocera) niogreta sp. nov. is most similar to B. (Tetradacus) brachycera (Bezzi, 1916), which is known from India, Bhutan, and China (Drew and Romig 2013). Both species have an incomplete black ' $T$ ' marking on the abdomen, and a costal band that follows vein $\mathrm{R}_{4+5}$ and expands distally to reach vein M. Bactrocera niogreta can be distinguished by the connection of the yellow presutural marking with the notopleuron, which resembles a yellow curly bracket ' $\{$ " in dorsal view. Bactrocera niogreta further has smaller facial spots, not filling the basal $1 / 2$ of the socket, and in the male genitalia it has a deep emargination of sternum V, which is shallow in B. brachycera. Bactrocera niogreta may in Sulawesi be most easily be confused with B. megaspilus, but the latter has a more angular expansion of the costal band, no medial black markings on the abdomen, no presutural yellow markings and all fulvous legs.

Molecular diagnostics. The COI sequence of Bactrocera niogreta is, in our database, most similar to Bactrocera fuscitibia, which can morphologically easily be distinguished by not having a clearly expanded costal band. The EF1-alpha sequences are most similar to B. enochra (Drew, 1972), which is morphologically different in not having a wide costal band, and has a wide red band medially across the scutum and three longitudinal black bands along the abdomen. Both COI and EF1-alpha are diagnostic to identify $B$. niogreta (See BOLD Dataset DOI: http://doi.org/10.5883/DS-DACSU).

Description of adult. Head (Fig. 3). All parts uniformly fulvous to yellow, ocellar triangle slightly darker. Face fulvous with rectangular spot in each antennal furrow. Antennae uniformly fulvous. Thorax (Figs 2, 4). Scutum and pleural areas black with narrow red-brown areas lateral of the yellow postsutural lateral vittae. Yellow markings: postpronotal lobes; notopleura; postsutular lateral vittae broad and parallel sided, reaching intra-alar seta; presutural marking to the lateral vittae that connects to the notopleura and in dorsal view resembles a curly bracket ' \{'; broad mesopleural stripe, almost reaching posterior level of postpronotal lobe, continuing onto katepisternum as a broad transverse spot, anterior margin slightly convex; katatergite; anatergite. Medial vitta absent. Scutellum yellow except for narrow black basal band. Setae: two scutellar; one prescutellar; one intraalar; one posterior supraalar; one anterior supraalar; one mesopleural; two notopleural; four scapular; all setae well developed and red-brown. Abdomen (Figs 2, 5). Oval to diamond shaped; terga free; pecten present on tergum III; posterior lobe of surstylus short (Fig. 7); abdominal sternum $V$ with a deep concavity on posterior margin that reaches the center of the sternum. Tergum I fulvous with apical margin narrowly yellow. Tergum II yellow with anteromedial dark marking. Tergum III mostly dark, with a narrow concave posterior fulvous band. Terga IV and 

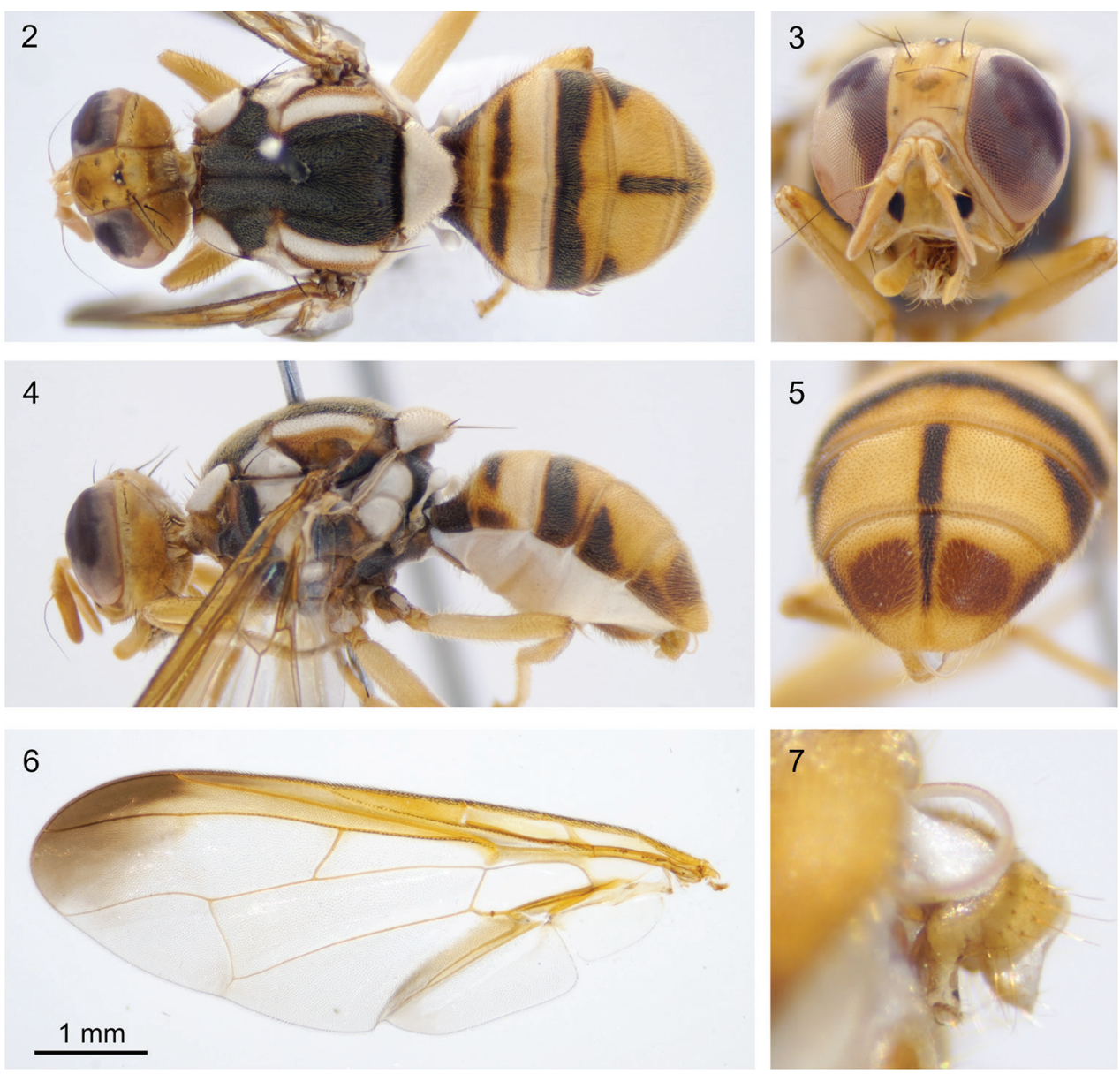

Figures 2-7. Bactrocera (Bactrocera) niogreta sp. nov. Holotype, ms09121 2 dorsal view 3 frontal view of the face $\mathbf{4}$ lateral view $\mathbf{5}$ posterior view of the abdomen showing the ceromatae $\mathbf{6}$ dissected wing $\mathbf{7}$ lateral close-up of the genitalia.

$\mathrm{V}$ with a medial longitudinal dark marking. Tergum IV with triangular anterolateral dark markings, tergum $\mathrm{V}$ with narrow anterolateral dark markings. Ceromatae (shining spots) contrasting red-brown. Legs (Fig. 4). All leg segments fulvous to yellow; tibiae fulvous with apical black spur on mid tibiae; tarsi fulvous to yellow. Wings (Fig. 6). Length $6.1 \mathrm{~mm}$, basal costal and costal cells fuscous, increasingly darker distally; microtrichia in outer corner of cell costal only; remainder of wings with a pale fulvous tint except fuscous subcostal (anal) cell; broad fuscous costal band that reaches vein $\mathrm{R}_{4+5}$, gradually darker distally until dark brown and expands to reach vein $\mathrm{M}$; a broad fuscous anal streak ending at apex of $\mathrm{A}_{1}+\mathrm{CuA}_{2}$; dense aggregation of microtrichia around $\mathrm{A}_{1}+\mathrm{CuA}_{2}$; supernumerary lobe not pronounced.

Male lure. Zingerone.

Host plant. Unknown. 
Etymology. The species name is an adjective that refers to instigator of the 20162019 Dacini surveys in Sulawesi: Jerome Niogret.

Comments. the morphology of $B$. niogreta overall most closely resembles $B$. (Tetradacus) brachycera, the combination of a short posterior lobe of the surstylus in the male genitalia and a deep concavity on sternum $\mathrm{V}$ support placement in subgenus Bactrocera. In the Drew and Romig (2016) key to the Southeast Asian fruit flies, B. niogreta characters lead to the Indian species Bactrocera (Bactrocera) andamanensis, couplet 90 on page 140. The key can there be adapted to include that $B$. niogreta differs from $B$. andamanensis in having an all-black scutum, broad postsutural yellow lateral vittae, and dark lateral markings on abdominal segment IV, with no dark markings on the legs.

\section{Dacus longicornis form icariiformis}

Dacus longicornis Wiedemann is a widespread Southeast Asian species that is a minor pest: the larvae feed on Luffa, Trichosanthes and some other Cucurbitaceae (Allwood et al. 1999; Drew et al. 1998; Hardy and Adachi 1954). The morphology of D. longicornis is most extensively treated by Drew et al. (1998), where many synonyms were established and the variability of the species was first documented. In particular, this was the first, and only, publication that noted two forms: "There are two forms of $D$. longicornis, one with and one without a small medial postsutural vitta" (Drew 1998). However, this knowledge was not incorporated in subsequent publications, such as the Drew and Romig (2013) treatment of the Southeast Asian fauna, nor the accompanying Drew and Romig (2016) identification keys. We here provide the first figures of both forms (Figs 8-13). The postsutural medial vitta is absent in Bangladesh specimens (Figs 8, 9), but always present in Sulawesi specimens (Figs 10-13), although sometimes indistinct (Fig. 10). The dark markings on the anterior sides of the abdominal segments are more pronounced in Bangladesh specimens of $D$. longicornis, and Bangladesh specimens have a dark band across the occiput, connecting the compound eyes. The variable presence or absence of a medial vitta is not known for any other Dacinae species, but with all data considered, we see no reason at present to establish this form as a new species. Both COI and EF1-alpha sequence data reveal some genetic substructure in D. longicornis, but the structure differs between the two markers and does not match with the morphological forms (Figs 14, 15). Drew and Romig (2013) had studied the type material of D. icariiformis Enderlein, from India, and concluded that of the three type specimens - no holotype had been designated- the female was actually $D$. longicornis and only the two males are now regarded as lectotype and paralectotype. This confusion indicates that it is difficult to distinguish $D$. longicornis from $D$. icariiformis, and we here refer to the specimens of $D$. longicornis with a medial vitta that are genetically indistinguishable as D. longicornis form icariiformis. Because we did not study any type material, we refrain from synonymizing $D$. icariiformis with $D$. longicornis. However, we note that there are no diagnostic characters indicated in the literature to distinguish $D$. longicornis form icariiformis from D. icariiformis. 

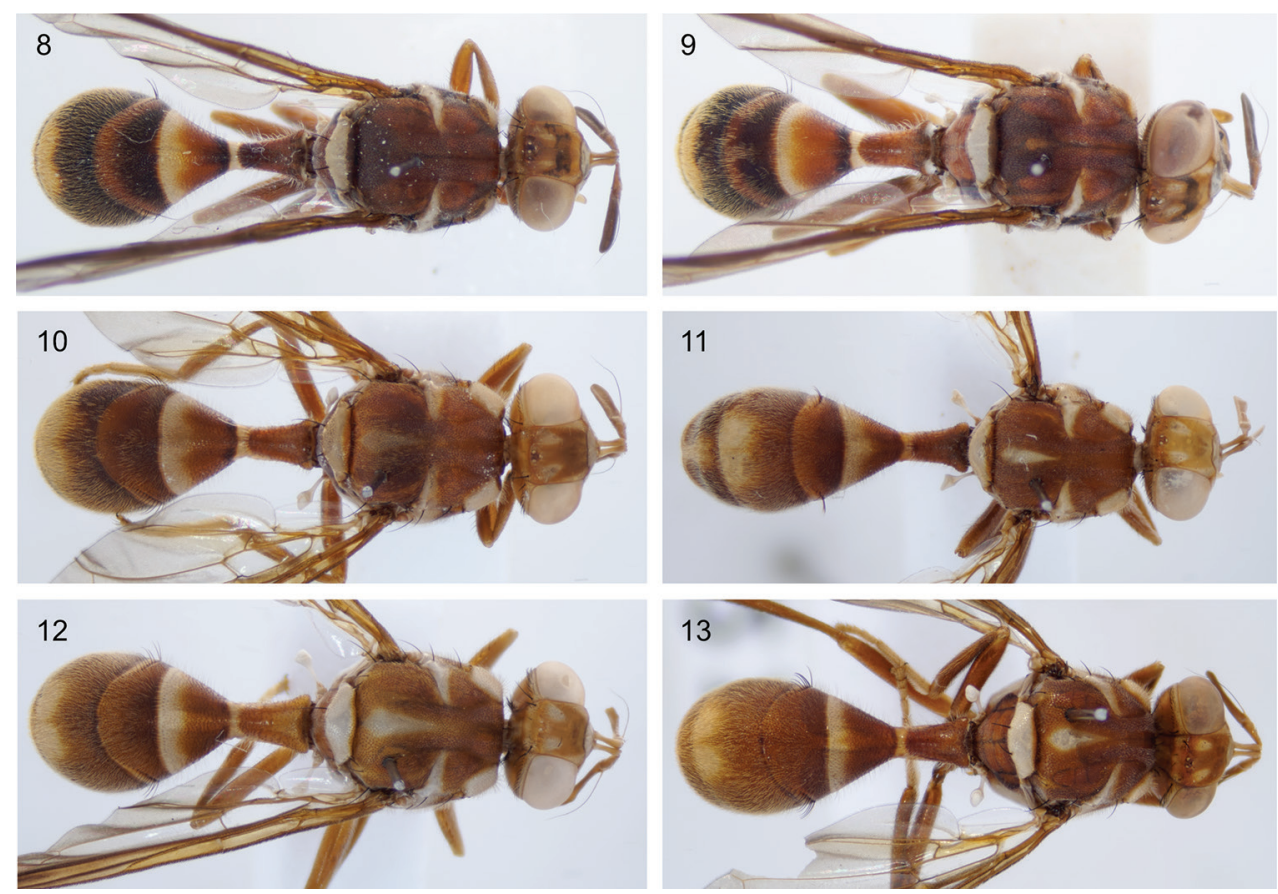

Figures 8-13. Two forms of Dacus longicornis 8 D. longicornis collected in Bangladesh, Pabna district, 30-ix-3-x-2013 Leg. M. A. Hossain 9 D. longicornis collected in Bangladesh, Maulvi Bazar Rainforest resort, Leg. L. Leblanc \& M. A. Hossain 10 specimen ms08424, collected in Sulawesi, with a faint medial postsutural yellow vitta I I specimen ms08432, collected in Sulawesi I 2 specimen ms08428, collected in Sulawesi I3 specimen ms08421, collected in Sulawesi.

\section{Sulawesi Bactrocera melastomatos}

We collected more than 300 specimens with a uniform morphotype that are tentatively included in the checklist as B. melastomatos (Table 1, Suppl. material 1: Table S1, Figs 16-19). We sequenced COI and EF1-alpha fragments for multiple specimens: they are genetically indistinguishable from specimens morphologically identified as B. rubigina (Wang \& Zhao, 1989), B. melastomatos and B. osbeckiae Drew \& Hancock, 1994 in both markers (Figs 20, 21). Morphologically, the specimens from Sulawesi are an imperfect fit for all three genetically suggested candidate species. Instead, they are more similar to the sympatric B. usitata Drew \& Hancock, 1994 (Figs 16-19), but $B$. usitata has a medial black line across abdominal segments III-V, forming the typical Bactrocera black ' $T$ ', which is never present in Sulawesi B. melastomatos. The costal band of B. usitata and B. melastomatos, including the Sulawesi specimens, extends to vein $\mathrm{R}_{4+5}$, a character also shared with the southern Vietnam form of $B$. rubigina (Drew and Romig 2013). In the Drew \& Romig (Drew and Romig 2016) identification keys, the absence of a black ' $\mathrm{T}$ ' shape on the abdomen will lead to Batrocera latifrons, but that species is not attracted to cue lure, and has parallel yellow lateral postsutural vittae, 

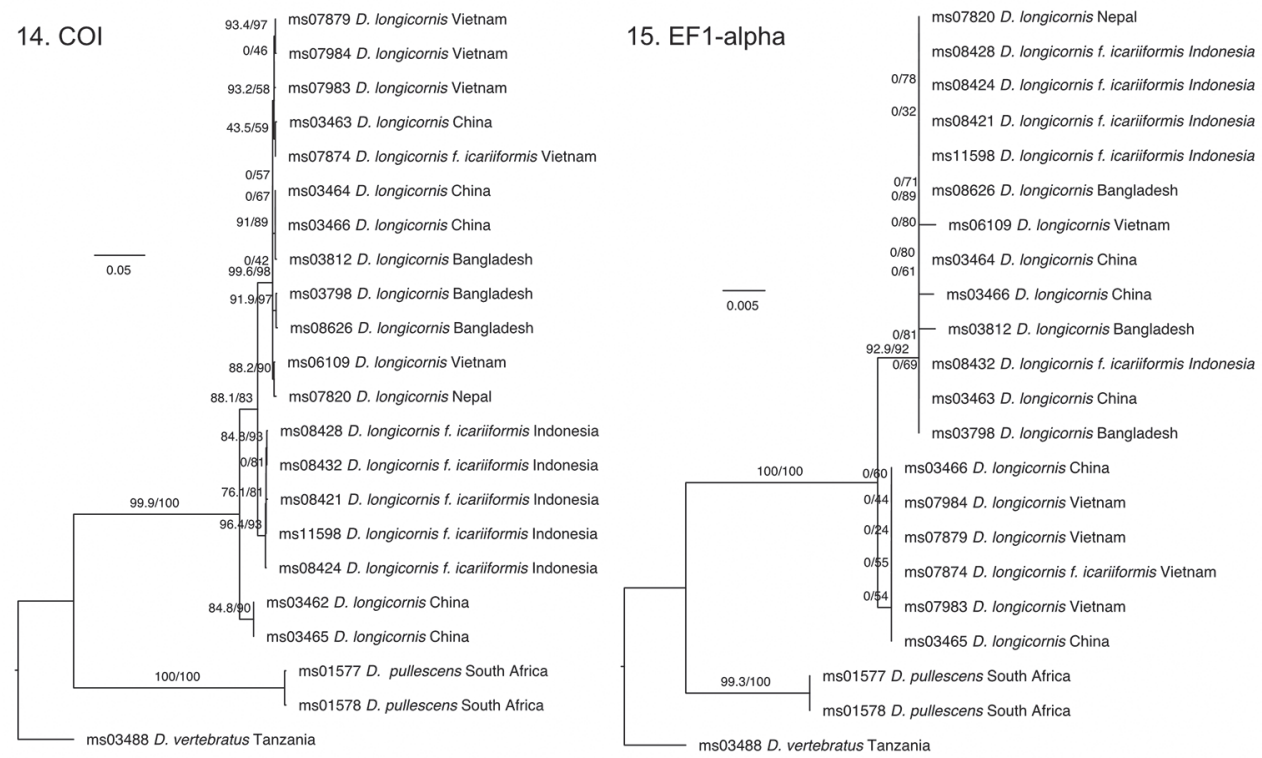

Figures I4, I 5. Maximum Likelihood trees based on COI (I4) and EF1-alpha (I5) DNA sequence data for Dacus longicornis, with $D$. pullescens Munro and D. vertebratus Bezzi as outgroups. Branch support values are rapid bootstrap values and approximate-likelihood ratio test values, scale bar indicates substitutions per site. Full details on the samples can be found in BOLD dataset DOI: http://dx.doi.org/10.5883/DS-DACSU.
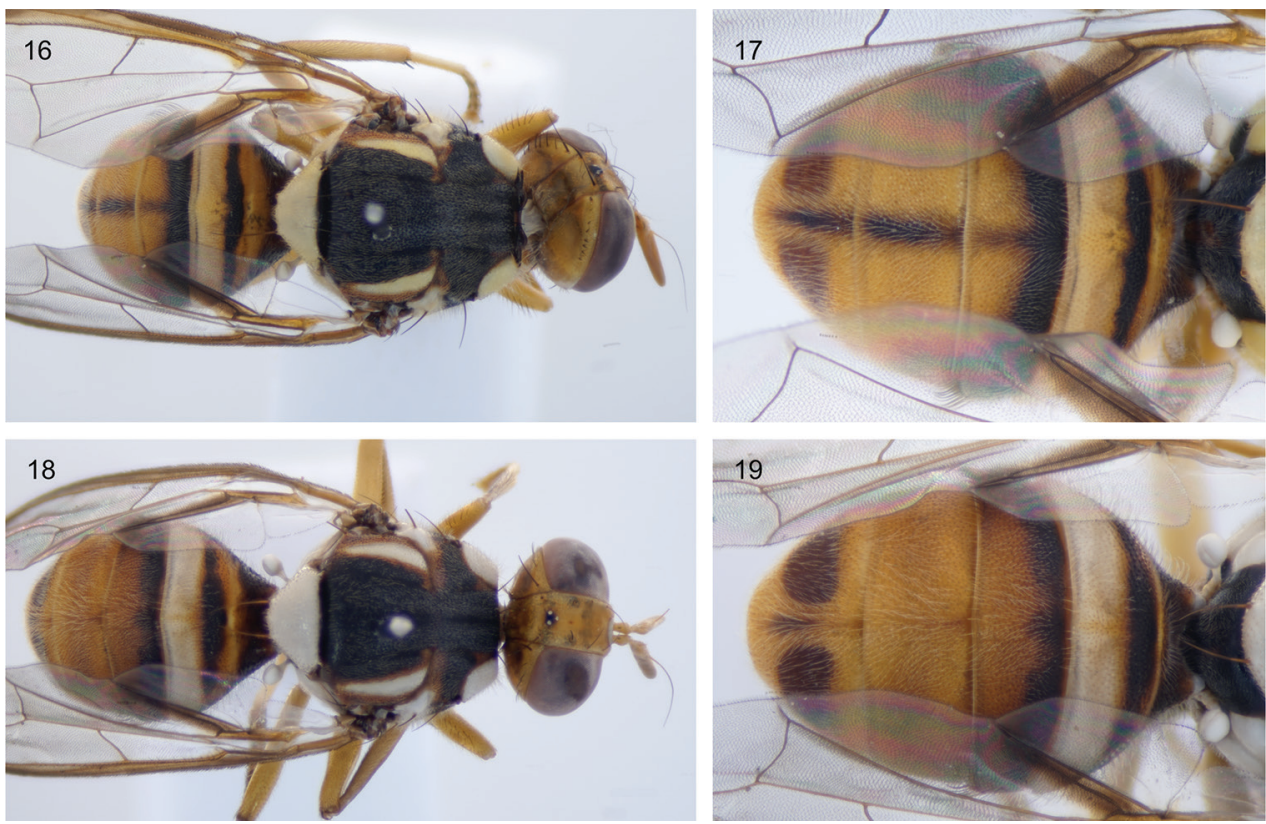

Figures 16-19. Sulawesi Bactrocera melastomatos resemble sympatric Bactrocera usitata $\mathbf{1 6}$ specimen ms09144 B. usitata, dorsal view $\mathbf{I}$ close up of abdomen of ms09144 18 specimen ms08838 B. melastomatos, dorsal view 19 close up of abdomen of ms08838. 

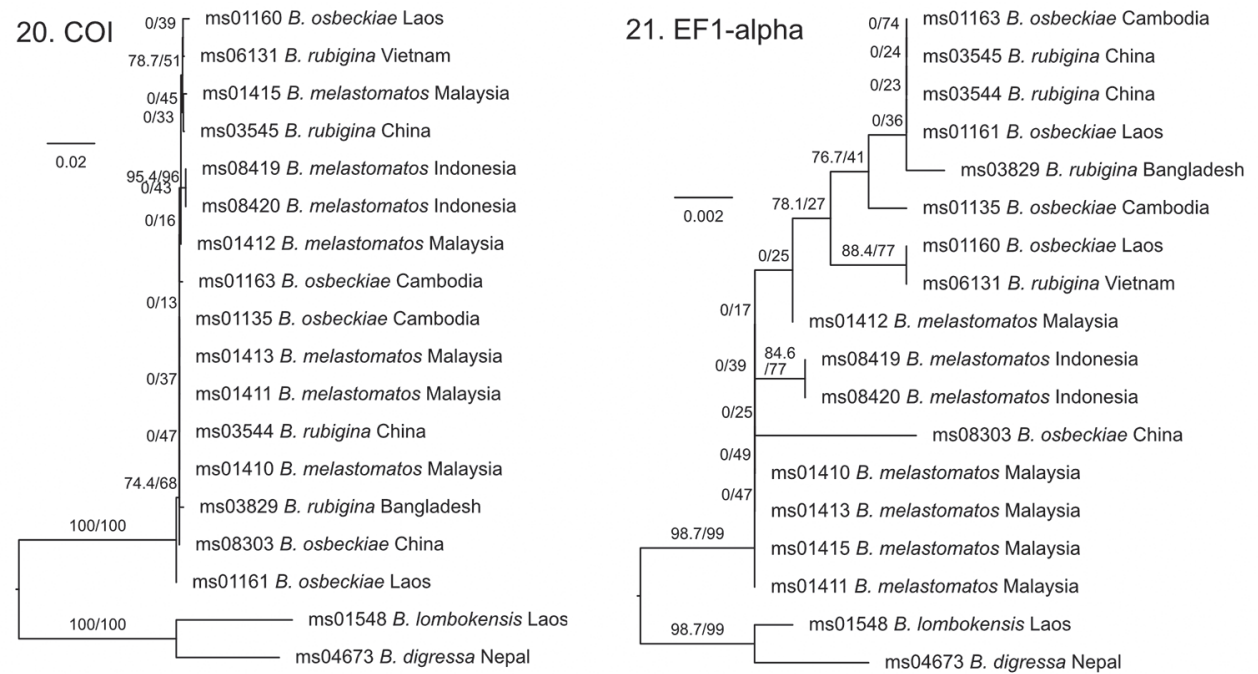

Figures 20, 2I. Maximum Likelihood trees based on COI (20) and EF1-alpha (2I) DNA sequence data for Bactrocera melastomatos and allied species, using B. lombokensis Drew \& Hancock and B. digressa Radhakrishnan as outgroup. Branch support values are rapid bootstrap values and approximate-likelihood ratio test values, scale bar indicates substitutions per site. Full details on the samples can be found in BOLD dataset DOI: http://dx.doi.org/10.5883/DS-DACSU.

which are strongly tapering, almost triangular, in Sulawesi B. melastomatos. Because there is no genetic support at present to describe this taxon as a separate species, we interpret the morphology of Sulawesi specimens as regional variation and leave their designation as $B$. melastomatos until more (genomic) data becomes available. Rearing specimens from host fruit would present important ecological data; the currently recorded hosts for this group are all Melastomataceae or Lauraceae (Liang et al. 1993; Allwood et al. 1999).

\section{Bactrocera carambolae Drew \& Hancock, 1994}

We collected two specimens of Bactrocera carambolae, both at the Insitu locality, which represent the first records for Sulawesi (Figs 22-25). The morphology of the collected specimens is consistent with the description (Drew and Hancock 1994). However, because $B$. carambolae is morphologically very similar to $B$. dorsalis and they have intermingled mitochondrial DNA (San Jose et al. 2018b), we confirmed the identification with EF1-alpha DNA sequences. EF1-alpha is diagnostic for this species pair based on five positions (see also Leblanc et al. 2019). Bactrocera carambolae was already known from Java and Borneo (Vargas et al. 2015), so its presence in Sulawesi could be through natural dispersal, and it may have been missed during previous surveys. Alternatively, it could have been introduced through fruit transport, as it is a pest species on commercial fruit. Its natural distribution includes Vietnam, 

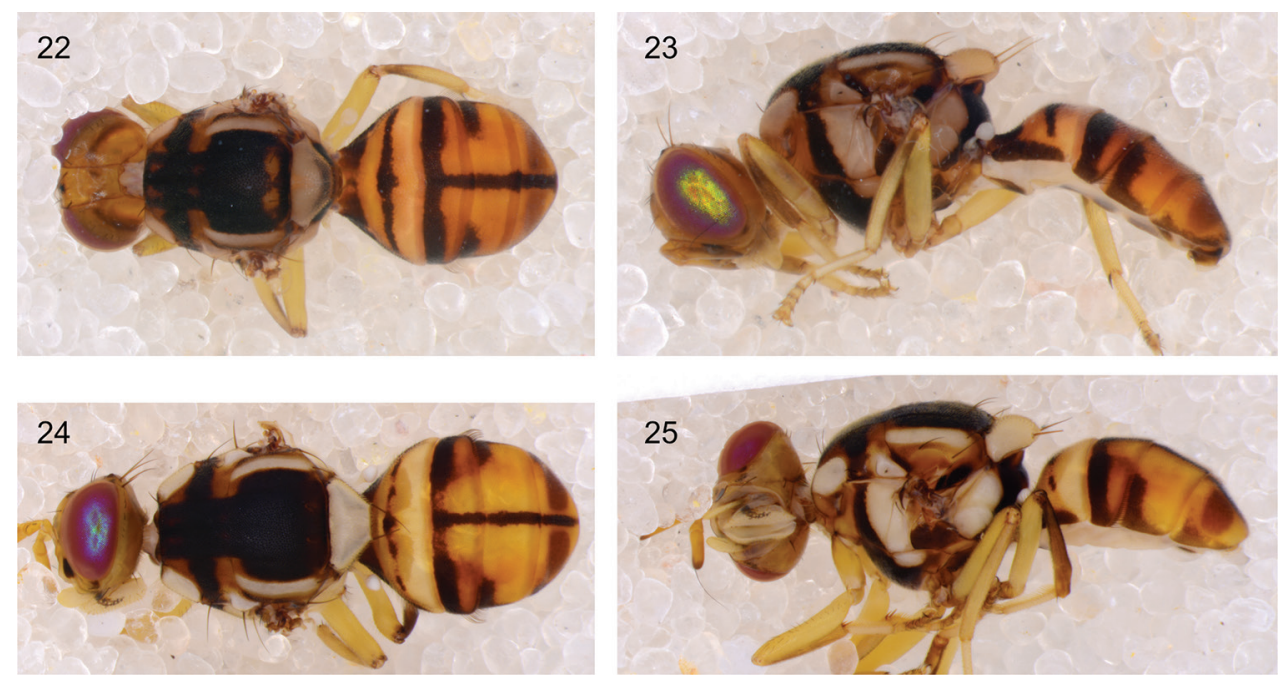

Figures 22-25. The two specimens of Bactrocera carambolae that represent the first records for Sulawesi, photographed in ethanol (wings were removed) 22 dorsal view of specimen ms08439 23 lateral view of specimens ms08439 24 dorsal view of specimen ms10710 25 lateral view of specimen ms10710. Both specimens have the typical rectangular black mark on the lateral sides of the fourth abdominal segment, but lack the black mark on the fore femur, which can further help to distinguish B. carambolae from $B$. dorsalis.

Laos, Cambodia, Thailand, Malaysia, and Indonesia (Java and Kalimantan), and it was recently reported in Bangladesh (Leblanc et al. 2019). In addition, it is highly invasive in agricultural areas in the Guianas in South America, where it is the only representative of Dacini.

\section{Dacus pullus (Hardy 1982)}

We record specimen ms09122 as a representative of Dacus pullus (Figs 26-31), although the wing markings are somewhat incongruent with the description and illustration of the only known other specimen of this species. The original species description states: "Costal band broad extending through upper half of cell Rs for its entire distance and expanded in apical portion to fill entire wing apex below upper edge of cell $2^{\text {nd }} M 2$ " (Hardy 1982). However, the illustration does not depict an expansion in the apical portion. Drew and Romig (2013) also illustrated the holotype, again not showing a significant apical expansion of the costal band. The costal band of specimen ms09122 is mostly confined by vein $\mathrm{R}_{4+5}$, although there is infuscation of crossvein $\mathrm{r}-\mathrm{m}$, and distally expands to cross vein $\mathrm{M}$. We opt to err on the side of caution and interpret this as intraspecific variation, and do not describe this specimen as a separate species, also considering the limited availability of material and the fact that both specimens were collected in Sulawesi. 

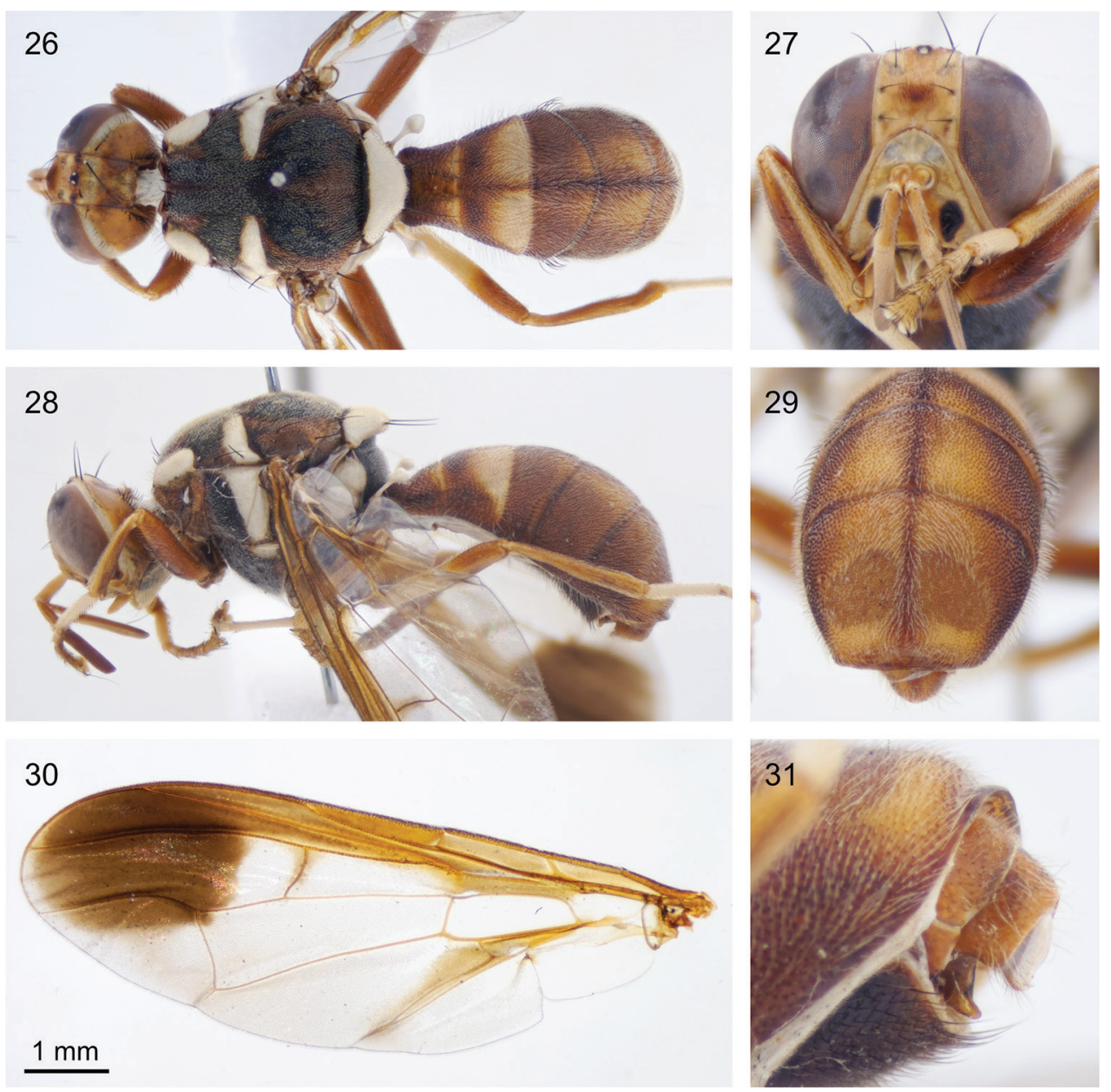

Figures 26-3 I. Dacus pullus $\mathbf{2 6}$ dorsal view $\mathbf{2 7}$ frontal view of the face $\mathbf{2 8}$ lateral view $\mathbf{2 9}$ posterior view of the abdomen showing the ceromae $\mathbf{3 0}$ dissected wing $\mathbf{3}$ I lateral close-up of the genitalia.

\section{Discussion}

\section{Between the lines}

Sulawesi is a dispersal crossroads for the biotas of Southeast Asia, Australia, and Oceania. The updated species checklist we present here shows that Sulawesi is unique, with many endemic species, but that there are also strong connections with Southeast Asia, at least for the taxa under study. This finding does not support the earlier working hypotheses that posited a closer connection to the Sahul fauna, including Papua (Hardy 1982). Based on this recent data, it seems likely that Wallacea has been a "stepping-stone" for Dacini to reach Australasia and Oceania; 30 Sulawesi species are also found in (former) 
Sunda, while only one is shared with Sahul. This can provide crucial insight into the timing of the diversification of the group in the latter areas. Wallacea, and Sulawesi with it, was separated in discontinuous landmasses with fluctuating sea-levels until the mid-Miocene, 10-15 Ma (Hall 2009). Before this connection, Sunda and Sahul were separated by vast oceanic distances that were unlikely to be crossed by fruit flies. There are currently hundreds of Dacini species known from Australia and Oceania (Drew 1989, Drew and Romig 2001), which may have resulted from rapid radiation after reaching these new areas of ecological opportunity. Similarly, the timing of the formation of Wallacea suggests a relatively recent origin for the 34 Sulawesi endemic Dacini species. However, it should be noted that the Dacini fauna of Papua is understudied (White and Evenhuis 1999) and further surveys in this area may reveal shared geographic ranges with some of the species now presumed to be Wallacean endemics.

It has been advocated by some that the categorization of biogeographic regions should follow more quantitative measures (Kreft and Jetz 2010), as opposed to the qualitative assessments from the early explorers. Using a non-metric multidimensional scaling approach across a wide range of taxa, Kreft and Jetz (2010) suggested that Lydekker's line was most appropriate for separating the Oriental region from Australasia. This agrees with our findings for Dacini, although, depending on the scale of the patterns in question, maintaining Wallacea as a separate biogeographic region can equally well be argued. Other authors have further included a phylogenetic component in the delimitation of biogeographic areas, which resulted in a suggested split of Wallacea: Sulawesi and the Lesser Sunda Islands were grouped with Southeast Asia into the Oriental region, whereas the Moluccas were grouped with Papua in the Oceanian region (Holt et al. 2013). However, none of these broad-scale assessments of biogeographic categorization include or consider invertebrate taxa. Moreover, as phytophagous insects, it might be expected that the biogeographic pattern of Dacini more closely tracks phytogeographic regions. A broad study that included 7,340 plant species across Southeast Asia suggested 'central Wallacea' [defined to encompass the Philippines, Sulawesi, lesser Sunda islands, Moluccas, and Java] as a separate region (van Welzen et al. 2011). This categorization is further corroborated by the climatic conditions; central Wallacea has a yearly dry season and monsoon, whereas both neighboring regions lack a prolonged dry season. For Dacini, we find few connections between the Philippines and Wallacea, but there are some, e.g., B. commensurata. Future surveys of the Papuan Dacini fauna, and placement of the Wallacean taxa in a phylogenetic framework, can further inform which biogeographic delimitation fits best with this group of fruit flies, and it is clear that more studies on invertebrate groups will be important to fully understand the biogeographic affinities of the islands that connect Asia with Australia and Oceania.

\section{Pests}

As a tropical island, Sulawesi has a rich diversity of fruiting plants and, consequently, insects that utilize them. Our surveys were performed in cacao plantations; the only Dacini that is known to feed on cacao is the polyphagous Bactrocera dorsalis (Allwood et al. 1999). However, we have never observed flies attempting to oviposit on cacao nor 
have we found maggots inside the pods. Cacao is likely a very rare host for $B$. dorsalis, if at all, and potentially only fallen and dehiscent fruit where the tough skin is cracked is susceptible. We commonly found $B$. dorsalis, but also another pest species; $B$. albistrigata at all sites. Together they made up $70.6 \%$ of all individuals collected. The host records of B. albistrigata include jackfruit (Artocarpus heterophyllus), jambu putik (Syzygium sp.), mango (Mangifera indica L.), guava (Psidium guajava L.) and rose apple (Syzygium sp.) some of which were planted near the cacao. It is interesting to note that although we encountered the cucurbit pest Zeugodacus cucurbitae, it was surprisingly rare. Possibly, this is due to the limited availability of melon hosts in the area (none were observed), although it is also known to feed on papaya, which were recurrent in the cacao orchards sampled, and non-commercial cucurbits that commonly occur as weeds in gardens and plantations. We further encountered small numbers of B. umbrosa, a pest of breadfruit (Artocarpus altilis) that has an extraordinarily wide distribution; it is the only species in the checklist that is known to be naturally dispersed across Southeast Asia, Wallacea, Australia and Oceania (Krosch et al. 2018). We suggest that, if desired, the population densities of pests in our survey areas can likely be decreased significantly with sanitation measures, most importantly the removal of fallen fruit and pruning of damaged fruit unfit for consumption.

\section{Acknowledgements}

We would like to thank Suparmi, Wulan, and Jerome Niogret for their contributions in the insect sampling, and Dan Nitta for his help with the molecular lab work. We are grateful to Luc Leblanc for helping with the identifications of the initial samples that were collected, and we thank Norman Barr for bringing CD and Jerome Niogret into contact. We thank the editor and reviewers for helpful comments that improved the manuscript. Funding for this project was provided by the United States Department of Agriculture (USDA) Farm Bill Section 10007 Plant Pest and Disease Management and Disaster Prevention Program in support of suggestion "Genomic approaches to fruit fly exclusion and pathway analysis": 3.0497-FY17, FY18 and FY19. These funds were managed by the University of Hawaii's College of Tropical Agriculture and Human Resources. This material was made possible, in part, by a Cooperative Agreement from the United States Department of Agriculture's Animal and Plant Health Inspection Service (APHIS). It may not necessarily express APHIS’ views. Additional funding was provided by the USDA Cooperative State Research, Education and Extension (CSREES) project HAW00942-H administered by the College of Tropical Agriculture and Human Resources, University of Hawaii.

\section{References}

Allwood AJ, Chinajariyawong A, Drew RAI, Hamacek EL, Hancock DL, Hengsawad C, Jipanin JC, Jirasurat M, Kong Krong C, Kritsaneepaiboon S, Leong CTS, Vijaysegaran S 
(1999) Host plant records for fruit flies (Diptera: Tephritidae). The Raffles Bulletin of Zoology Supplement 7: 1-92.

Doorenweerd C, Leblanc L, Norrbom AS, San Jose M, Rubinoff D (2018) A global checklist for the 932 fruit fly species in the tribe Dacini (Diptera: Tephritidae). ZooKeys 730: 19-56. https://doi.org/10.3897/zookeys.730.21786

Drew RAI (1989) The tropical fruit flies (Diptera: Tephritidae: Dacinae) of the Australasian and Oceanian regions. Memoirs of the Queensland Museum 1: 1-536.

Drew RAI, Hancock DL (1994) The Bactrocera dorsalis complex of fruit flies (Diptera: Tephritidae: Dacinae) in Asia. Bulletin of Entomological Research Supplement Series 2: 1-68. https://doi.org/10.1017/S1367426900000278

Drew RAI, Romig MC (2001) The fruit fly fauna (Diptera: Tephritidae: Dacinae) of Bougainville, the Solomon Islands and Vanuatu. Australian Journal of Entomology 40: 113-150. https://doi.org/10.1046/j.1440-6055.2001.00222.x

Drew RAI, Romig MC (2013) Tropical Fruit Flies of South-East Asia. CABI, Oxfordshire, 655 pp.

Drew RAI, Romig MC (2016) Keys to the Tropical Fruit Flies of South-East Asia. CABI Publishing, 487 pp.

Dupuis JR, Bremer FT, Kauwe A, San Jose M, Leblanc L, Rubinoff D, Geib SM (2018) HiMAP: Robust phylogenomics from highly multiplexed amplicon sequencing. Molecular Ecology Resources 18: 1000-1019. https://doi.org/10.1111/1755-0998.12783

Ekesi S, De Meyer M, Mohamed SA, Virgilio M, Borgemeister C (2016) Taxonomy, Ecology, and Management of Native and Exotic Fruit Fly Species in Africa. Annual Review of Entomology 61: 219-238. https://doi.org/10.1146/annurev-ento-010715-023603

Hall R (1998) The plate tectonics of Cenozoic SE Asia and the distribution of land and sea. Biogeography and Geological Evolution of SE Asia: 99-131.

Hall R (2009) Southeast Asia's changing palaeogeography. Blumea: Journal of Plant Taxonomy and Plant Geography 54: 148-161. https://doi.org/10.3767/000651909X475941

Hardy DE (1982) The Dacini of Sulawesi (Diptera: Tephritidae). Treubia 28: 173-241.

Hardy DE, Adachi MS (1954) Studies in the fruit flies of the Philippine Islands, Indonesia and Malaya. Part 1. Dacini (Tephritidae-Diptera). Pacific Science 8: 147-204.

Holt BG, Lessard J-P, Borregaard MK, Fritz SA, Araujo MB, Dimitrov D, Fabre P-H, Graham CH, Graves GR, Jonsson KA, Nogues-Bravo D, Wang Z, Whittaker RJ, Fjeldsa J, Rahbek C (2013) An update of Wallace's zoogeographic regions of the world. Science 339: 74-79. https://doi.org/10.1126/science.1228282

Huxley TH (1868) On the Classification and Distribution of the Alectoromorphae and Heteromorphae. Proceedings of the Zoological Society London 1868: 294-319.

Kreft H, Jetz W (2010) A framework for delineating biogeographical regions based on species distributions. Journal of Biogeography 37: 2029-2053. https://doi.org/10.1111/j.13652699.2010.02375.x

Krosch MN, Schutze MK, Newman J, Strutt F, Bryant LM, McMahon J, Clarke AR (2018) In the footsteps of Wallace: population structure in the breadfruit fruit fly, Bactrocera umbrosa (F.) (Diptera: Tephritidae), suggests disjunction across the Indo-Australian Archipelago. Austral Entomology. https://doi.org/10.1111/aen.12375

Leblanc L, Hossain MA, Doorenweerd C, Khan SA, Momen M, San Jose M, Rubinoff D (2019) Six years of fruit fly surveys in Bangladesh: a new species, 33 new country records 
and discovery of the highly invasive Bactrocera carambolae (Diptera, Tephritidae). ZooKeys 876: 87-109. https://doi.org/10.3897/zookeys.876.38096

Liang GQ, Hancock DL, Xu W, Liang F (1993) Notes on the Dacinae of southern China (Diptera: Tephritidae). Journal of the Australian Entomological Society 32: 137-140. https:// doi.org/10.1111/j.1440-6055.1993.tb00561.x

Lydekker R (1896) A Geographical History of Mammals. University Press, Cambridge, 428 pp. https://doi.org/10.5962/bhl.title.31155

Mayr E (1944) Wallace's line in the light of recent zoogeographic studies. The Quarterly Review of Biology 19: 1-14. https://doi.org/10.1086/394684

Nguyen LT, Schmidt HA, Von Haeseler A, Minh BQ (2015) IQ-TREE: A fast and effective stochastic algorithm for estimating maximum-likelihood phylogenies. Molecular Biology and Evolution 32: 268-274. https://doi.org/10.1093/molbev/msu300

San Jose M, Doorenweerd C, Leblanc L, Barr N, Geib S, Rubinoff D (2018a) Incongruence between molecules and morphology: a seven-gene phylogeny of Dacini fruit flies paves the way for reclassification (Diptera: Tephritidae). Molecular Phylogenetics and Evolution 121: 139-149. https://doi.org/10.1016/j.ympev.2017.12.001

San Jose M, Doorenweerd C, Leblanc L, Barr N, Geib S, Rubinoff D (2018b) Tracking the Origins of Fly Invasions; Using Mitochondrial Haplotype Diversity to Identify Potential Source Populations in Two Genetically Intertwined Fruit Fly Species (Bactrocera carambolae and Bactrocera dorsalis [Diptera: Tephritidae]). Journal of Economic Entomology: 1-13. https://doi.org/10.1093/jee/toy272

Schutze MK, Virgilio M, Norrbom A, Clarke AR (2017) Tephritid Integrative Taxonomy: Where We Are Now, with a Focus on the Resolution of Three Tropical Fruit Fly Species Complexes. Annual Review of Entomology 62: 147-164. https://doi.org/10.1146/ annurev-ento-031616-035518

Schutze MK, Aketarawong N, Amornsak W, Armstrong KF, Augustinos AA, Barr N, Bo W, Bourtzis K, Boykin LM, CÁCeres C, Cameron SL, Chapman TA, Chinvinijkul S, ChomiČ A, De Meyer M, Drosopoulou E, Englezou A, Ekesi S, Gariou-Papalexiou A, Geib SM, Hailstones D, Hasanuzzaman M, Haymer D, Hee AKW, Hendrichs J, Jessup A, Ji Q, Khamis FM, Krosch MN, Leblanc LUC, Mahmood K, Malacrida AR, MavraganiTsipidou P, Mwatawala M, Nishida R, Ono H, Reyes J, Rubinoff D, San Jose M, Shelly TE, Srikachar S, Tan KH, Thanaphum S, Haq I, Vijaysegaran S, Wee SL, Yesmin F, Zacharopoulou A, Clarke AR (2015) Synonymization of key pest species within the Bactrocera dorsalis species complex (Diptera: Tephritidae): taxonomic changes based on a review of 20 years of integrative morphological, molecular, cytogenetic, behavioural and chemoecological data. Systematic Entomology 40: 456-471. https://doi.org/10.1111/syen.12113

Simpson GG (1977) Too many lines; the limits of the Oriental and Australian zoogeographic regions. Proceedings of the American Philosophical Society 121: 107-120.

Spakman W, Hall R (2010) Surface deformation and slab-mantle interaction during Banda Arc subduction rollback. Nature Geoscience 3: 562-566. https://doi.org/10.1038/ngeo917

Vargas RI, Pinero JC, Leblanc L (2015) An overview of pest species of Bactrocera fruit flies (Diptera: Tephritidae) and the integration of biopesticides with other biological approaches for their management with a focus on the pacific region. Insects 6: 297-318. https://doi. org/10.3390/insects6020297 
Wallace AR (1860) On the Zoological Geography of the Malay Archipelago. Zoological Journal of the Linnaean Society London 4: 172-184. https://doi.org/10.1111/j.1096-3642.1860. tb00090.x

Wallace AR (1876) The Geographical Distribution of Animals with a Study of the Relations of Living and Extinct Faunas as Elucidating the Past Changes of the Earth's Surface. Macmillan \& Co., London, 154 pp. https://doi.org/10.5962/bhl.title.46581

van Welzen PC, Parnell JAN, Slik JWF (2011) Wallace's Line and plant distributions: Two or three phytogeographical areas and where to group Java? Biological Journal of the Linnean Society 103: 531-545. https://doi.org/10.1111/j.1095-8312.2011.01647.x

White IM, Evenhuis NL (1999) New species and records of Indo-Australian Dacini (Diptera: Tephritidae). The Raffles Bulletin of Zoology 47(2): 487-540.

Whitmore TC (1982) Wallace's Line: A Result of Plate Tectonics. Annals of the Missouri Botanical Garden 69: 668. https://doi.org/10.2307/2399087

\section{Supplementary material I}

\section{Table S1}

Authors: Camiel Doorenweerd, Arni Ekayanti, Daniel Rubinoff

Data type: Spreadsheet with trapping records

Explanation note: Table including the lot numbers for each trapping event, fly identification, fly counts, lure used and exact locality.

Copyright notice: This dataset is made available under the Open Database License (http://opendatacommons.org/licenses/odbl/1.0/). The Open Database License $(\mathrm{ODbL})$ is a license agreement intended to allow users to freely share, modify, and use this Dataset while maintaining this same freedom for others, provided that the original source and author(s) are credited.

Link: https://doi.org/10.3897/zookeys.973.55327.suppl1 